Four of the prominent affiliated societies, namely, the American Society of Naturalists, the American Society of Zoologists, the Botanical Society of America, and the Genetics Society of America, held a joint session on December 30 on the theme "Biology and Society". Prof. W. M. Wheeler spoke on "Animal Societies", Prof. E. A. Hooton on "Primitive Human Societies", and Prof. F. H. Hankins on "Development of Modern Social Organization". 'The American Society of Parasitologists and the section of Medical Sciences in joint session presented a programme on the "Typhus Group of Organisms", with demonstrations which aroused great interest. Other joint sessions of affiliated societies on plant physiology, ecology, entomology, phytopathology, parasitology and dental research would merit special comment if space permitted.

On December 30 the American Society of Naturalists celebrated its semi-centennial anniversary. Prof. S. H. Gage was honorary chairman. After dinner the anniversary address was delivered by Prof. E. G. Conklin on "Fifty Years of the American Society of Naturalists". Prof. B. E. Livingston read his presidential address on "Environments".

The addresses of the retiring vice-presidents, given at various times, included the following: Mathematics, Prof. H. H. Mitchell, "Linear Groups and Finite Geometries"; Physics, Dr. D. L. Webster, "Current Progress in X-Ray Physics"; Chemistry, Dr. Frank C. Whitmore, "Some General Aspects of the Polymerization and Depolymerization of Olefins"'; Astronomy, Dr. P. W. Merrill, "Invisible Star Light" ; Geology and Geography, Dr. William H. Hobbs, "The Glaciers of Mountains and Continents"; Zoology, Prof. A. S. Pearse, "Ecological Segregation"'; Botany, Dr. H. L. Shantz, "Botanical Research"; Anthropology, Dr. C. H. Danforth, "Genetics and Physical Anthropology"; Psychology, Dr. Walter S. Hunter, "The Stimulus Control of Behavior during and after Learning"'; Education, Prof. Stuart A. Courtis, "Differential Testing as a Method of Psychological Analysis"; Social and Economic Sciences, Prof. William F. Ogburn, "Recent Trends in Social Sciences"; Historical and Philological Sciences, Dr. Waldo G. Leland, "Recent Trends in the Humanities"; Engineering, Prof. Dugald C. Jackson, "The Origins of Engineering"; Medical Sciences, Dr. C. R. Stockard, "Internal Secretions and Genetic Quality in Structural Development"; Agriculture, Prof. Joseph H. Gourley, "Plant Anatomy as a Tool in Agricultural Research".

The Science Exhibition, now a regular feature of the annual meeting, was, despite adverse economic conditions, the most successful yet undertaken. Colleges, private and Government research laboratories presented new and important work, both in pure and applied science; commercial exhibits of apparatus and products were extensive; among the displays of publications in science those of university presses were conspicuous, and the exhibits made by associations of teachers in biology, physics and mathematics attracted marked attention.

The Committee on the Place of Science in Educa. tion had arranged a special conference in which relations between teaching and the advancement of science were discussed from diverse points, and the results of new experiments in laboratories, science clubs and State academies reported.

The American Association prize of 1,000 dollars was awarded by the Committee on Awards to Dr. Reuben L. Kahn, bacteriologist of the University of Michigan, for his paper on "Tissue Reactions in Immunity: the Specific Reacting Capacities of Different Tissues of an Immunized Animal". By a method of measuring the degree of immunity acquired by different tissues, as shown by the author's investigations, warfare against germ diseases may be more successfully conducted.

The British Association was represented at the meeting by Prof. Arthur E. Kennelly of Harvard and Prof. F. E. Lloyd of MeGill ; the French Association by Prof. W. M. Davis of Harvard, and the Bohemian Royal Society by Prof. Henry B. Ward of Illinois. Special delegates were also appointed by many American institutions.

The following officers were elected for the year 1934: President, E. L. Thorndike of Columbia University; Council Members, F. K. Richtmyer of Cornell University, J. C. Merriam of Carnegie Institution; Members of the Executive Committee, K. T. Compton of the Massachusetts Institute of Technology, E. G. Conklin of Princeton University; Trustee of Science Service for three years, to April 1937: J. McKeen Cattell; Vice-Presidents of the Sections, 1934: R. D. Carmichael, mathematics ; H. G. Gale, physies; Joel H. Hildebrand, chemistry ; Frederick Slocum, astronomy ; Jas. B. Macelwane, geology and geography; George L. Streeter, zoological sciences; B. O. Dodge, botanical sciences; M. J. Herskovitz, anthropology ; John E. Anderson, psychology; Carl Snyden, social and economic sciences; Solon J. Buck, historical and philological sciences; C. E. Skinner, engineering; Cyrus C. Sturgis, medical sciences ; J. G. Lipman, agriculture ; Guy T. Buswell, education; Secretary of Section I, John A. McGeoch.

\title{
Invention and Legislation
}

$\mathrm{A}^{\mathrm{T}}$ the sixth annual general meeting of the Television Society held at University College, London, on March 14, an address was given by the president, Sir Ambrose Fleming, on "Invention in Relation to National Welfare and its Legislative Control". Sir Ambrose referred to progress in television as an instance of one of the most interesting of the technical applications of science. It fulfils the same function with regard to the eye that radiotelephony does for the ear. It annihilates distance and enables us to see living and moving objects which would otherwise be invisible. In short, it enables us to be in two places at the same time.
We are then led to consider the question how such an achievement can be made to contribute to national welfare, apart from its interest as a mere scientific novelty or amusement.

The great advances made in the use of short electric waves and closer scanning, and in photoelectric cells and cathode ray tubes, have made corresponding advances possible in television, and we can now transmit images of pictures, diagrams, or living persons and reproduce them on screens $3-4 \mathrm{ft}$. square, visible to large audiences at the receiving stations. We have in this ability a valuable means of education. Lectures and school lessons can be 
given by radio speech and illustrated by television diagrams or pictures. Botany, astronomy, physiology and other sciences can thus be taught by visible diagrams. A critic might say that this will diminish the demand for science teachers. On the other hand, it would render possible the services of very able men and women of special knowledge and teaching power. This particular application of television has scarcely yet been touched. Where mere entertain. ment is desired, it will before long be possible to transmit special films of moving objects and, as it were, to bring the cinema into every home.

These replacements which invention brings about force us into consideration of the question how far mechanical invention at the present day is responsible for the large scale unemployment which afflicts the world ? Different answers are given to this question. Some hold that the replacement of manual power and skill by machine power which does ten or hundred times as much in the same time, is a fundamental cause of present distresses. Others think that a primary reason is the deficient organisation in business, and that our methods of production have outrun our power of distribution. Probably a still more basic cause is the enormous waste of world wealth and natural resources in wars and preparation for wars. Humanity has not yet learnt how to live as one family or society and not as a collection of enemies and contesting rivals.

Invention, however, requires guidance and control, and it is difficult to introduce new methods and ideas when any one branch of activity has become centralised in a few hands or petrified by becoming a Govermment monopoly. This makes it necessary to point out how many disadvantages arise from erroneous or premature legislation intended to control invention. This may be illustrated by the history of telegraphy, telephony, electric lighting and wireless telegraphy. When after 1837 electric telegraphy became practicable by numerous inventions, public companies were formed to exploit it. About 1866 or so, an opposition began to be raised to the growth of what was called another 'monopoly'. The British Government of that day then passed Acts of Parliament in 1868-69 to enable it to buy out the telegraph companies and to place electric telegraphy under the control of the General Post Office.

These Acts were, however, drawn with such skill that even ten years later when the telephone was invented and exchanges established, telephony was held to be subject to the above Acts. Unfortunately, this decision rested merely on a judgment given in a court of first instance and was never confirmed by a higher court. The General Post Office offered the telephone companies a licence for thirty years in exchange for a royalty of 10 per cent on their receipts. During those thirty years it took nearly a million and a half sterling from the telephone, but it blocked the way to advances in the art during all that time.

The same story was repeated with electric incandescent domestic lighting. In 1882 the Government passed an Act ironically termed an Act to "facilitate" it, but in fact it simply 'throttled' it for six years until an amending Act was carried in 1886. A similar fate attended wireless telegraphy. In 1904 it was placed under the control of the Postmaster-General. In 1926, when broadcasting of speech and music had become an important service, a charter committed it to the domination of the B.B.C. and its small group of governors. Television is now also in the control of the same power and the only chance given to prove its utility is at 11 p.m., when few people have use for it.

Accordingly it is clear that premature legislation can easily cripple a nascent industry and bind it in bandages of red tape. It is beyond defence that an invention which was not dreamt of at the date of a certain Act of Parliament should be controlled by that Act.

In conclusion, Sir Ambrose Fleming advocated an extension of the period of patent protection, which at present is fourteen years in Great Britain, unless specially extended. An invention is no use to the public until it becomes practically available or com. mercialised, and this generally requires time and great expenditure. It is not possible to secure this without some reasonable prospect of return upon the capital, and in most cases a large part of the period of patent protection has elapsed before the point of commercial success is reached.

\section{University and Educational Intelligence}

CAmbridge.-Dr. R. Stoneley, lecturer in applied mathematics in the University of Leeds, and Dr. H. M. Taylor have been appointed University lecturers in mathematics.

The Vice-Chancellor has appointed Dr. A. H. Gardiner to the Frazer lectureship in social anthropology for the year 1934-35.

Dr. W. H. Thorpe and Dr. W. H. Mills have been appointed to represent the University at the Eighth International Ornithological Congress to be held in Oxford on Juiy $2-7$.

Prof. E. B. Verney, professor of pharmacology at University College, London, has been appointed to the Sheild readership in pharmacology as from October 1.

EdinBURGR.-The Senatus Academicus of the University has resolved that the honorary doctorate in laws be offered to the following, among others, for conferment at the graduation ceremonial to be held on June 28: Dr. R. Hutchison, physician to the London Hospital; Sir John Stirling-Maxwell, formerly chairman of the Forestry Commission and of the Royal Fine Art Commission for Scotland, chairman of the Ancient Monuments Board (Scotland); Prof. R. Robinson, Waynflete professor of chemistry in the University of Oxford; Prof. D'Arcy W. Thompson, professor of natural history in the University of St. Andrews.

Applications, which must be received not later than April 15, are invited for the following scholarships awarded by the Council of the Institution of Electrical Engineers. Inquiries for full particulars and nomination forms (specifically mentioning the name of the Scholarship) should be addressed to the Secretary of the Institution, Savoy Place, London, W.C.2 : Duddell scholarship (£150 per annum for 3 years), for candidates less than nineteen years of age on July 1; Ferranti scholarship (£250 per annum for 2 years), for candidates less than twenty-six years of age on July 1 ; Swan memorial scholarship ( $£ 120$ for 1 year), for candidates less than twenty-seven years of age on July 1; Silvanus Thompson scholarship (£100 per annum and tuition fees, for 2 years), for works employees less than twenty-two years of age on July 1 . 